\title{
EFEKTIVITAS MODEL GROUP INVESTIGATION BERBANTUAN MEDIA WATAK KALINYAMATAN TERHADAP PEMAHAMAN KONSEP SISWA
}

\author{
Nurlaely Dwi Astuti, Muhammad Noor Ahsin, dan Siti Masfuah
}

Universitas Muria Kudus

Email: nurlailydwi13@gmail.com; noor.ahsin@umk.ac.id; siti.masfuah@umk.ac.id

\begin{tabular}{l}
\hline Info Artikel \\
\hline \\
Sejarah Artikel: \\
Diterima 14 Juli 2020 \\
Direvisi 05 Agustus 2020 \\
Disetujui 07 Agustus 2020 \\
\hline
\end{tabular}

Keywords:

group investigation, watak kalinyamatan media, concept understanding

\begin{abstract}
This study aims to measure the improvement of students' understanding and also to measure students' learning activities after learning through the Group Investigation (GI) assisted by Watak Kalinyamatan media.

This type of research is an experimental research design with Pre Experiment Design. The sample in this study was grade IV SDN 1 Damarjati, with the total of 45 students. Sampling was done by using Purposive Random Sampling technique. Data collection techniques used observation, interviews, tests, and documentation. In Analyzing the data used the final data analysis which includes the normality test, description of the concept understanding analysis, description of the students' activity description, and hypothesis test that includes $n$-gain test and t-test.

The results of the analysis in this study were (1) there was an improvement in students' understanding of the concepts before and after the GI model of the Watak Kalinyamatan media was applied to the students, (2) P-value $=0.039>0.025 \mathrm{H}_{0}$ was accepted, this means that the average post-test score of students' concept understanding through the GI model assisted by the Watak Kalinyamatan media received a score of $\geq 65$, (3) In the learning activities of the students' meeting 2, 3 and $4 P$-value $=0.1075,0.045$, and $0.037 \geq 0.025, H_{0}$ is accepte, this means that the students' activities after being given learning through GI models assisted by the Watak Kalinyamatan media are $\geq 65$.
\end{abstract}

\begin{abstract}
Abstrak
Penelitian ini bertujuan untuk mengukur peningkatan pemahaman konsep dan mengukur aktivitas belajar siswa setelah diberi pembelajaran melalui model Group Investigation (GI) berbantuan media Watak Kalinyamatan.

Jenis penelitian ini adalah penelitian eksperimen dengan desain Pre Experiment Designs. Sampel dalam penelitian ini yaitu kelas IV SDN 1 Damarjati yang berjumlah 45 siswa. Pengambilan sampel dilakukan dengan teknik Purposive Random Sampling. Teknik pengumpulan data menggunakan observasi, wawancara, tes, dan dokumentasi. Analisis data yang digunakan tahap akhir meliputi uji normalitas, analisis deskripsi pemahaman konsep, analisis deskripsi aktivitas siswa, dan uji hipotesis dengan uji n-gain dan uji t.

Hasil analisis dalam penelitian ini adalah (1) terjadi peningkatan pemahaman konsep siswa sebelum dan setelah diterapkan model GI berbantuan media Watak Kalinyamatan, (2) $P$ value $=0.039>0.025$ maka $\mathrm{H}_{0}$ diterima, artinya rata-rata nilai posttest pemahaman konsep siswa melalui model GI berbantuan media Watak Kalinyamatan mendapatkan nilai $\geq 65$, (3) aktivitas belajar siswa pertemuan 2,3 dan 4 P-value $=0.1075,0.045$, dan $0.037 \geq 0,025$ maka $\mathrm{H}_{0}$ diterima, artinya aktivitas siswa setelah diberikan pembelajaran melalui model GI berbantuan media Watak Kalinyamatan $\geq 65$.
\end{abstract}


Nurlaely Dwi Astuti, Muhammad Noor Ahsin, dan Siti Masfuah

EFEKTIVITAS MODEL GROUP INVESTIGATION BERBANTUAN MEDIA WATAK KALINYAMATAN ... WASIS: Jurnal Ilmiah Kependidikan. Volume 1, Nomor 2, November 2020, hlm. 60-67

\section{PENDAHULUAN}

Kurikulum berkaitan langsung dengan kualitas pendidikan. Fujiawati (2016) berpendapat bahwa kurikulum adalah alat yang dapat menjamin berhasilnya proses pendidikan, tanpa kurikulum yang baik dan tepat maka tujuan dan sasaran pendidikan yang dicita-citakan akan sulit untuk dicapai. Pemerintah saat ini menerapkan kurikulum 2013, dimana (1) semua kompetensi didukung dalam setiap mata pelajaran, (2) antara mata pelajaran satu dengan yang lain saling terkait, (3) seluruh mata pelajaran dilaksanakan terkait dan terpadu dengan pendekatan Saintifik. Karena penerapan kurikulum saat ini adalah kurikulum 2013, dimana semua mata pelajaran dikaitkan satu dengan yang lain, untuk itu penelitian ini mengambil dua muatan, yaitu Ilmu Pengetahuan Sosial (IPS) dan Ilmu Pengetahuan Alam (IPA).

Hasil observasi dan wawancara studi pendahuluan yang dilaksanakan dengan guru dan salah satu siswa kelas IV SDN 1 Damarjati tanggal 10 Juli 2019 diketahui bahwa guru sudah memanfaatkan media dalam pembelajaran khususnya tematik dengan muatan IPA dan IPS, tetapi media yang di gunakan masih terbatas pada media yang sudah tersedia di sekolah. Aktivitas siswa rendah dalam mengikuti kegiatan pembelajaran. Siswa merasa kesulitan dalam memahami materi yang banyak teorinya, selain itu siswa mudah bosan dan motivasi belajar siswa rendah. Hal tersebut membuat siswa cenderung terlihat pasif dalam proses pembelajaran.

Hasil tes pemahaman konsep yang dilaksanakan pada tanggal 7 Oktober 2019 di SDN 1 Damarjati kelas IV dengan jumlah 45 siswa menunjukkan bahwa pemahaman konsep rendah. Rata-rata hasil tes pemahaman konsep kelas IV adalah 48,46. Terdapat 6 siswa mencapai KKM 65 dengan kategori cukup dan selebihnya 39 siswa belum mencapai KKM dengan kategori kurang. Berdasarkan hasil tes pemahaman konsep tersebut terlihat bahwa selama ini pembelajaran belum terlaksana secara maksimal. Hal ini terbukti dengan hasil tes pemahaman konsep siswa yang belum mencapai Kriteria Ketuntasan Minimal (KKM). Mardapi, dkk (2015) berpendapat bahwa pada kurikulum 2013, keberhasilan siswa dapat dilihat dari penguasaan siswa pada kompetensi tertentu yang telah ditetapkan dalam kurikulum. Siswa dikatakan telah menguasai kurikulum jika kemampuan hasil belajar siswa telah mencapai Kriteria Ketuntasan Minimal (KKM).

Salah satu upaya yang dapat dilaksanakan guru dalam meningkatkan pemahaman siswa terhadap konsep dan aktivitas siswa adalah dengan cara perbaikan proses pembelajaran . Untuk itu upaya yang dilakukan untuk memperbaiki permasalahan di kelas IV SDN 1 Damarjati yaitu dengan diterapkannya model pembelajaran kooperatif tipe Group Investigation (GI) dalam pembelajaran.

Shoimin (2014) berpendapat bahwa GI adalah salah satu model pembelajaran kooperatif yang menekankan partisipasi aktif siswa dalam mencari sendiri materi pelajaran yang akan dipelajari dengan memanfaatkan buku pelajaran atau internet serta menempatkan siswa dalam kelompok untuk melaksanakan Investigasi terhadap suatu topik. Penggunaan model Pembelajaran Group Investigation efektif dilakukan dalam upaya meningkatkan pemahaman konsep siswa, karena dalam menggunakan model ini siswa dituntut untuk aktif menemukan materi pelajarannya sendiri, hal ini menciptakan ingatan yang kuat pada diri siswa terhadap materi pelajaran yang ditemukannya. Hal ini diperkuat dengan penelitian yang dilakukan oleh Pranata (2016) didapatkan bahwa terjadi peningkatan pemahaman konsep siswa setelah diimplementasikannya model pembelajaran Group Investigation.

Penggunaan media pembelajaran dalam proses pembelajaran sama pentingnya untuk dilakukan untuk menumbuhkan motivasi belajar dan aktivitas siswa. Penggunaan media dapat memudahkan guru dalam menyampaikan materi pelajaran. Hal tersebut diperkuat oleh Sukiman (2012) yang berpendapat bahwa, media pembelajaran merupakan alat yang dapat dimanfaatkan untuk menyalurkan pesan dari pengirim ke penerima sehingga merangsang pikiran, perasaan, perhatian dan minat serta kemauan siswa sehingga tujuan pembelajaran tercapai secara efektif. Selain penerapan model Group Investigation dalam proses pembelajaran, penelitian ini menggunakan media Watak Kalinyamatan "Wayang Peta Kearifan Lokal Kalinyamatan" dalam membantu kegiatan belajar mengajar.

Media Watak Kalinyamatan merupakan media pembelajaran yang mengintegrasikan media dengan kearifan lokal. Media ini dapat dimainkan langsung oleh siswa. Media ini berisi peta Kecamatan Kalinyamatan yang dilengkapi dengan kartu lalu lintas dan kartu desa sebagai alat dalam memainkannya. Kartu lalu lintas berisi arah jalan lokasi tujuan, sedangkan kartu desa berisi informasi-informasi desa yang dilengkapi dengan gambar-gambar pekerjaan sekitar yang dikaitkan dengan cita-cita dan daur hidup 
Nurlaely Dwi Astuti, Muhammad Noor Ahsin, dan Siti Masfuah

EFEKTIVITAS MODEL GROUP INVESTIGATION BERBANTUAN MEDIA WATAK KALINYAMATAN ... WASIS: Jurnal Ilmiah Kependidikan. Volume 1, Nomor 2, November 2020, hlm. 60-67

beberapa jenis makhluk hidup untuk membantu siswa dalam memahami materi pelajarannya.

Penggunaan kartu desa yang dilengkapi dengan gambar-gambar dapat mendorong motivasi dan aktivitas belajar siswa, dengan gambar-gambar tersebut siswa tidak mudah bosan dalam mengikuti kegiatan belajar. Zafira dan Artharina (2017) menyatakan bahwa penggunaan media pembelajaran dapat menarik perhatian siswa terhadap pembelajaran. Media pembelajaran yang dapat dimainkan langsung oleh siswa dapat menjadikan siswa tertarik dan aktif dalam kegiatan belajar. Hal tersebut selaras dengan pendapat Kristin (2018) bahwa karakteristik anak SD yang senang bermain dan senang bergerak membuat guru harus melaksanakan pembelajaran yang menyenangkan dan membuat siswa dapat belajar sambil bermain. Adanya media pembelajaran membuat siswa termotivasi dalam mengikuti kegiatan pembelajaran. Ardianti, dkk (2019) berpendapat bahwa pembelajaran yang menyenangkan akan membantu siswa belajar dalam suasana bebas dari tekanan dan dapat menumbuhkan motivasi belajar siswa yang berdampak pada peningkatan pemahaman konsep siswa. Peneliti berharap media ini dapat membantu peningkatan pemahaman konsep IPS dan IPA khususnya materi sumber daya alam dan siklus hidup beberapa jenis makhluk hidup, menghilangkan anggapan siswa bahwa IPS dan IPA adalah muatan yang sulit dan banyak menghafal, dan meningkatkan aktivitas belajar siswa. Penggunaan media tersebut, didukung oleh penelitian Siregar (2017) tentang penggunaan media gambar didapatkan bahwa terjadi peningkatan nilai rata-rata kelas secara signifikan.

Tujuan penelitian inii meliputi: 1) mengkaji peningkatan kemampuan pemahaman konsep siswa kelas IV SDN 1 Damarjati sebelum dan sesudah diterapkan pembelajaran menggunakan model Group Investigation berbantuan media Watak Kalinyamatan, 2) menganalisis kemampuan pemahaman konsep siswa kelas IV SDN 1 Damarjati melalui pembelajaran model Group Investigation berbantuan media Watak Kalinyamatan mencapai KKM 65, 3) menganalisis aktivitas belajar siswa kelas IV SDN 1 Damarjati setelah diberikan pembelajaran menggunakan model Group Investigation berbantuan media Watak Kalinyamatan mencapai 65.

\section{METODE PENELITIAN}

Penelitian ini merupakan jenis penelitian kuantitatif dengan desain Pre Experiment Designs. Pre Experiment Designs belum merupakan eksperimen sungguh-sungguh, karena masih terdapat variabel luar yang ikut berpengaruh terhadap terbentuknya variabel dependen (Sugiyono, 2016). Penelitian ini berfokus pada desain One Group Pretest Posttest Design. Pada desain ini terdapat satu kelompok yang diberi pretest sebelum diberikan perlakuan dan diberi posttes setelah diberikan perlakuan.

Populasi pada penelitian ini yaitu Gugus Bungtomo Kecamatan Kalinyamatan Kabupaten Jepara Tahun Ajaran 2020/ 2021 yang meliputi SDN 1 Damarjati, SDN 2 Damarjati, SDN 3 Damarjati, dan SDN 4 Damarjati. Teknik pengambilan sampel penelitian ini menggunakan teknik purposive random sampling. Sampel yang diambil dalam penelitian ini yaitu kelas IV SDN 1 Damarjati. Anggota sampel pada penelitian ini berjumlah 45 siswa yang terdiri atas 25 siswa laki-laki dan 20 siswa perempuan. Semua siswa yang dijadikan anggota sampel dalam penelitian melaksanakan pembelajaran dengan model Group Investigation berbantuan Media Watak Kalinyamatan.

Data dalam penelitian ini diperoleh dengan teknik tes, observasi, wawancara, dan dokumentasi.. Instrumen yang digunakan berupa lembar tes kemampuan pemahaman konsep, lembar pedoman observasi, lembar pedoman wawancara, dan dokumentasi. Analisis data dalam penelitian ini yaitu analisis data tahap awal dan analisis data tahap akhir. Analisis data tahap awal yaitu uji normalitas dengan menganalisis nilai pretest, sedangkan analisis data tahap akhir yaitu uji normalitas, analisis deskripsi pemahaman konsep, analisis deskripsi aktivitas belajar siswa, dan uji hipotesis. Uji hipotesis yang digunakan yaitu uji peningkatan pemahaman konsep (uji n-gain), uji t deskriptif pemahaman konsep, dan uji t deskriptif aktivitas siswa.

\section{HASIL DAN PEMBAHASAN}

Uji normalitas sebagai uji tahap awal dilaksanakan untuk mengukur apakah data nilai pretest pemahaman konsep berdistribusi normal atau tidak. Uji normalitas akan dilakukan dengan menggunakan rumus Kolmogorov Smirnov dengan hipotesis yang diajukan sebagai berikut.

$\mathrm{H}_{0}$ : data berdistribusi normal

$\mathrm{H}_{\mathrm{a}}$ : data tidak berdistribusi normal 
Nurlaely Dwi Astuti, Muhammad Noor Ahsin, dan Siti Masfuah

EFEKTIVITAS MODEL GROUP INVESTIGATION BERBANTUAN MEDIA WATAK KALINYAMATAN ... WASIS: Jurnal Ilmiah Kependidikan. Volume 1, Nomor 2, November 2020, hlm. 60-67

Berdasarkan uji Kolmogorov Smirnov, konsep dapat dilihat pada Tabel 1 hasil uji normalitas nilai pretest pemahaman

Tabel 1 Hasil Uji Normalitas Nilai Pretest Pemahaman Konsep Tests of Normality

\begin{tabular}{lcccccr}
\hline & \multicolumn{3}{c}{ Kolmogorov-Smirnov } & \multicolumn{3}{c}{ Shapiro-Wilk } \\
\cline { 2 - 7 } & Statistic & df & Sig. & Statistic & df & Sig. \\
\hline $\begin{array}{c}\text { Nilai Pretest Pemahaman } \\
\text { Konsep }\end{array}$ & .097 & 45 & $.200^{*}$ & .968 & 45 & .251 \\
\hline *. This is a lower bound of the true significance. & & & & & \\
a. Lilliefors Significance Correction
\end{tabular}

Berdasarkan Tabel 1 hasil uji normalitas nilai pretest pemahaman konsep kelas IV SDN 1 Damarjati didapatkan bahwa nilai signifikansi sebesar 0,200. Karena 0,200>0,05 maka $\mathrm{H}_{0}$ diterima yang berarti nilai pretest pemahaman konsep kelas IV SDN 1 Damarjati berdistribusi normal. Selanjutnya dilakukan analisis data tahap akhir untuk mengukur apakah data nilai posttest pemahaman konsep berdistribusi normal atau tidak. Hipotesis yang diajukan sebagai berikut.

$\mathrm{H}_{0}$ : data berdistribusi normal

$\mathrm{H}_{\mathrm{a}}$ : data tidak berdistribusi normal

Berdasarkan uji Kolmogorov Smirnov, hasil uji normalitas nilai posttest pemahaman konsep dapat dilihat pada Tabel 2

Tabel 2 Hasil Uji Normalitas Nilai Posttest Pemahaman Konsep Tests of Normality

\begin{tabular}{|c|c|c|c|c|c|c|}
\hline & \multicolumn{3}{|c|}{ Kolmogorov-Smirnova } & \multicolumn{3}{|c|}{ Shapiro-Wilk } \\
\hline & Statistic & $\mathrm{df}$ & Sig. & Statistic & $\mathrm{df}$ & Sig. \\
\hline $\begin{array}{c}\text { Nilai Posttest Pemahaman } \\
\text { Konsep }\end{array}$ & .128 & 45 & .062 & .945 & 45 & .034 \\
\hline
\end{tabular}

Berdasarkan Tabel 2 hasil uji normalitas nilai posttest pemahaman konsep kelas IV SDN 1 Damarjati didapatkan bahwa nilai signifikansi sebesar 0,062. Karena 0,062>0,05 maka $\mathrm{H}_{0}$ diterima artinya nilai posttest pemahaman konsep kelas IV SDN 1 Damarjati berdistribusi normal.

\section{Uji Peningkatan Kemampuan Pemahaman Konsep}

Uji N-gain dilakukan untuk menguji peningkatan pemahaman konsep siswa sebelum dan setelah diterapkan model Group Investigation berbantuan media Watak Kalinyamatan. Adapun hipotesis yang diajukan sebagai berikut.
Ho: terdapat peningkatan kemampuan pemahaman konsep siswa kelas IV SDN 1 Damarjati sebelum dan sesudah diterapkan pembelajaran menggunakan model Group Investigation berbantuan media Watak Kalinyamatan.

Ha: tidak terdapat peningkatan kemampuan pemahaman konsep siswa kelas IV SDN 1 Damarjati sebelum dan sesudah diterapkan pembelajaran menggunakan model Group Investigation berbantuan media Watak Kalinyamatan.

Nilai N-gain didapatkan dari selisih antara nilai posttest dan nilai pretest. Hasil analisis peningkatan kemampuan pemahaman konsep siswa dapat dilihat pada Tabel 3 
Nurlaely Dwi Astuti, Muhammad Noor Ahsin, dan Siti Masfuah

EFEKTIVITAS MODEL GROUP INVESTIGATION BERBANTUAN MEDIA WATAK KALINYAMATAN ... WASIS: Jurnal Ilmiah Kependidikan. Volume 1, Nomor 2, November 2020, hlm. 60-67

Tabel 3 Hasil Uji Peningkatan Kemampuan Pemahaman Konsep (Uji N-Gain)

\begin{tabular}{|c|c|c|c|c|c|c|}
\hline \multirow[b]{2}{*}{ No } & \multirow[b]{2}{*}{ Indikator Pemahaman Konsep } & \multicolumn{2}{|c|}{ Rata-rata } & \multirow[b]{2}{*}{ Gain } & \multirow[b]{2}{*}{ N-Gain } & \multirow[b]{2}{*}{ Kriteria } \\
\hline & & $\begin{array}{c}\text { Nilai Pretest } \\
\text { Tiap Indikator }\end{array}$ & $\begin{array}{l}\text { Nilai Posttest } \\
\text { Tiap Indikator }\end{array}$ & & & \\
\hline 1 & Menyatakan ulang sebuah konsep & 53,33 & 71,11 & 17,78 & 0,38 & Sedang \\
\hline 2 & $\begin{array}{l}\text { Mengklasifikasi objek menurut sifat-sifat tertentu } \\
\text { sesuai dengan konsepnya. }\end{array}$ & 53,05 & 72,5 & 19,45 & 0,41 & Sedang \\
\hline 3 & $\begin{array}{l}\text { Memberi contoh dan bukan contoh dari suatu } \\
\text { konsep. }\end{array}$ & 48,05 & 68,05 & 20 & 0,38 & Sedang \\
\hline 4 & $\begin{array}{l}\text { Menyajikan konsep dalam berbagai bentuk } \\
\text { representasi matematis. }\end{array}$ & 46,94 & 66,38 & 19,44 & 0,36 & Sedang \\
\hline 5 & $\begin{array}{l}\text { Mengembangkan syarat perlu atau syarat cukup } \\
\text { dari suatu konsep. }\end{array}$ & 40,27 & 62,5 & 22,23 & 0,37 & Sedang \\
\hline 6 & $\begin{array}{l}\text { Menggunakan dan memanfaatkan serta memilih } \\
\text { prosedur atau operasi tertentu. }\end{array}$ & 49,16 & 67,22 & 18,06 & 0,35 & Sedang \\
\hline 7 & $\begin{array}{l}\text { Mengaplikasikan konsep atau algoritma pada } \\
\text { pemecahan masalah. }\end{array}$ & 38,05 & 61,11 & 23,06 & 0,37 & Sedang \\
\hline & Rata-rata Nilai Tiap Indikator & 46,98 & 66,97 & 20,00 & 0,37 & Sedang \\
\hline
\end{tabular}

Berdasarkan Tabel 3 didapatkan bahwa terjadi peningkatan pemahaman konsep setelah diberikan pembelajaran dengan model Group Investigation berbantuan media Watak Kalinyamatan. Hal ini dibuktikan dengan nilai rata-rata hasil pretest pemahaman konsep dan nilai rata-rata hasil posttest pemahaman konsep tiap indikator yang meningkat, yaitu nilai ratarata hasil pretest tiap indikator sebesar 46,98 meningkat pada saat posttest dengan rata-rata nilai tiap indikator 66,97. Peningkatan pada semua indikator, dari indikator 1 sampai indikator 7 masuk pada peningkatan dengan kriteria sedang.

Peningkatan pemahaman konsep siswa disebabkan karena penerapan model Group Investigation berbantuan media Watak Kalinyamatan. Penerapan model Group Investigation menjadikan siswa lebih aktif dalam mencari materi pelajaran yang dipelajarinya, yaitu dengan menginvestigasi topik pembelajaran yang akan dipelajari. Hal ini sesuai dengan Hal ini sesuai dengan Putr (2017) berpendapat bahwa Group invstigation merupakan model pembelajaran berkelompok yang menuntut dan melibatkan siswa secara maksimal untuk berpikir tingkat tinggi dalam kegiatan pembelajaran. Sependapat dengan Khotimah (2016) bahwa model Group Investigation merupakan model kooperatif yang dapat merangsang kemampuan berpikir mandiri siswa dalam menanggapi suatu permasalahan dengan menginvestigasi suatu topik bahasan, dengan mencari sendiri materi pembelajaran dalam buku, membuat laporan diskusi dan mempresentasikan di depan kelas. Selain itu dalam proses pembelajaran siswa menginvestigasi topik pembelajaran dengan menggunakan media Watak Kalinyamatan. Media ini mengajak siswa belajar sambil bermain sehingga siswa aktif dan antusias dalam pembelajaran. Hal ini sesuai dengan penelitian Winarsih (2017) bahwa penerapan model pembelajaran tematik dan metode bermain dapat meningkatkan minat dan hasil belajar siswa kela II SDN Dukuh mencek 03 Kecamatan Sukorambi Kabupaten Jember.Selaras dengan pendapat Ardianti, dkk (2019) bahwa pembelajaran dengan permainan dapat menciptakan suasana belajar tanpa tekanan yang akan memberikan dampak positif pada peningkatan hasil belajar.

Siswa kelas IV SDN 1 Damarjati lebih aktif dan antusias saat diberikan pembelajaran menggunakan model Group Investigation berbantuan media Watak Kalinyamatan. Seluruh kelompok berlomba-lomba dalam mencari materi pembelajaran dan menginvestigasi topik pembelajaran yang didapatkannya. Semua siswa terlihat aktif berdiskusi dalam kelompoknya untuk menjawab setiap pertanyaan-pertanyaan yang dijumpainya dalam permainan Watak Kalinyamatan. Permainan Watak Kalinyamatan memiliki aturan-aturan permainan yang menuntut seluruh siswa aktif dalam memainkannya. Permainan ini berisi peta Kecamatan Kalinyamatan yang dilengkapi dengan kartu peta, kartu info desa, dan kartu lalu lintas yang dilengkapi dengan gambar-gambar. Juliarto, dkk (2020) berpendapat bahwa penggunaan media yang berkaitan dengan lingkungan local sekitar membuat siswa tertarik dan senang dalam pembelajaran. Hal ini membuat pembelajaran dengan model Group investigation berbantuan media Watak Kalinyamatan dapat menumbuhkan motivasi dan aktivitas belajar siswa kelas IV SDN 1 Damarjati meningkat. Hal ini sesuai dengan Lestari (2017) yang berpendapat bahwa model Group Investigation menuntut semua anggota kelompok untuk merencanakan suatu penelitian beserta perencanaan penyelesaian masalah yang dihadapi. Senada dengan pendapat Ningsih, dkk 
Nurlaely Dwi Astuti, Muhammad Noor Ahsin, dan Siti Masfuah

EFEKTIVITAS MODEL GROUP INVESTIGATION BERBANTUAN MEDIA WATAK KALINYAMATAN ... WASIS: Jurnal Ilmiah Kependidikan. Volume 1, Nomor 2, November 2020, hlm. 60-67

(2020) bahwa model Group Investigation menjadikan pembelajaran berpusat pada siswa sehingga semua siswa aktif dalam kegiatan pembelajaran. Kelompok menentukan apa saja yang akan dikerjakan dan siapa saja yang akan melaksanakannya serta bagaimana perencanaan penyajian di depan kelas

\section{Uji t Deskriptif Pemahaman Konsep}

Pada penelitian ini, uji $t$ deskriptif pemahaman konsep dilakukan untuk mengukur apakah model Group Investigation berbantuan media Watak Kalinyamatan efektif terhadap pemahaman konsep kelas IV SDN 1 Damarjati. Uji $t$ deskriptif pemahaman konsep pada penelitian ini menggunakan uji t satu pihak, yaitu pihak kiri. Uji t deskriptif pemahaman konsep dalam penelitian ini menggunakan nilai posttest dengan didasarkan pada nilai Kriteria Ketuntasan Minimal (KKM) ranah pengetahuan yaitu 65 . Adapun hipotesis yang diajukan sebagai berikut
Ho: rata-rata kemampuan pemahaman konsep siswa kelas IV SDN 1 Damarjati dengan pembelajaran model Group Investigation berbantuan media Watak Kalinyamatan $\geq$ 65.

Ha: rata-rata kemampuan pemahaman konsep siswa kelas IV SDN 1 Damarjati dengan pembelajaran model Group Investigation berbantuan media Watak Kalinyamatan < 65

Pengambilan keputusan dan penarikan kesimpulan menggunakan taraf kepercayaan $95 \%$ dengan kriteria, jika $P$-value $>1 / 2 \alpha$, maka $\mathrm{H}_{0}$ diterima dan jika $P$-value $\leq 1 / 2 \alpha$, maka $\mathrm{H}_{0}$ ditolak. Karena pengujian yang dilakukan adalah uji satu pihak (uji pihak kiri), maka $P$-value $=1 / 2 \times$ nilai sig. (2-tailed). Hasil uji t deskriptif pemahaman konsep siswa dapat dilihat pada Tabel 4

Tabel 4 Hasil Uji t Deskriptif Pemahaman Konsep Siswa

\begin{tabular}{|c|c|c|c|c|c|c|}
\hline \multicolumn{7}{|c|}{ One-Sample Test } \\
\hline & \multicolumn{6}{|c|}{ Test Value $=65$} \\
\hline & \multirow[b]{2}{*}{$\mathrm{T}$} & \multirow[b]{2}{*}{$\mathrm{df}$} & \multirow[b]{2}{*}{ Sig. (2-tailed) } & \multirow{2}{*}{$\begin{array}{c}\text { Mean } \\
\text { Difference }\end{array}$} & \multicolumn{2}{|c|}{$\begin{array}{l}\text { 95\% Confidence Interval of } \\
\text { the Difference }\end{array}$} \\
\hline & & & & & Lower & Upper \\
\hline $\begin{array}{c}\text { Nilai Posttest } \\
\text { Pemahaman Konsep }\end{array}$ & 1.800 & 44 & .079 & 1.911 & -.23 & 4.05 \\
\hline
\end{tabular}

Berdasarkan hasil uji $\mathrm{t}$ deskriptif pemahaman konsep siswa pada Tabel 4, didapatkan bahwa nilai sig. (2-tailed) sebesar 0,079. $P$-value $=1 / 2 \times 0,079=0,039$. Karena $P$ value $>1 / 2 \alpha,(0,039>0,025)$ maka $\mathrm{H}_{0}$ diterima dan dapat disimpulkan bahwa rata-rata nilai posttest pemahaman konsep siswa mendapatkan nilai $\geq 65$. Artinya rata-rata nilai posttest kemampuan pemahaman konsep siswa kelas IV SDN 1 Damarjati dengan pembelajaran model Group Investigation berbantuan media Watak Kalinyamatan lebih dari atau sama dengan KKM.

Berdasarkan hasil uji $t$ deskriptif pemahaman konsep, nilai rata-rata siswa kelas IV SDN 1 Damarjati setelah diberikan perlakuan dapat memenuhi KKM. Hal ini membuktikan bahwa model pembelajaran Group Investigation berbantuan media Watak Kalinyamatan efektif dilakukan terhadap pemahaman konsep siswa.

Berdasarkan analisis di atas, didapatkan bahwa ketuntasan pemahaman konsep siswa setelah diberikan perlakuan memenuhi KKM sebanyak $64 \%$. Berdasarkan hasil pengamatan, rendahnya pemahaman konsep siswa dalam mengaplikasikan konsep atau algoritma pada pemecahan masalah terjadi karena dalam memecahkan suatu permasalahan siswa kurang teliti dalam menuliskan urutan daur hidup beberapa hewan sehingga nilai rata-rata siswa cenderung rendah. Pada akhir pembelajaran guru meminta untuk memeriksa kembali jawaban yang telah dikerjakan siswa untuk menghindari kesalahan yang mungkin terjadi. Hal ini sesuai dengan Polya dalam Cahyani (2016) bahwa salah satu tahap pemecahan masalah yaitu melihat kembali hasil yang diperoleh.

\section{Uji t Deskriptif Aktivitas Belajar Siswa}

Pada penelitian ini, uji $\mathrm{t}$ deskriptif aktivitas belajar siswa dilakukan untuk mengukur apakah pembelajaran dengan model Group Investigation berbantuan media Watak Kalinyamatan efektif terhadap aktivitas belajar siswa kelas IV SDN 1 Damarjati. Uji t deskriptif pada penelitian ini menggunakan uji t satu pihak, yaitu pihak kiri. Nilai yang digunakan pada uji $\mathrm{t}$ deskriptif aktivitas belajar siswa yaitu nilai hasil 
Nurlaely Dwi Astuti, Muhammad Noor Ahsin, dan Siti Masfuah

EFEKTIVITAS MODEL GROUP INVESTIGATION BERBANTUAN MEDIA WATAK KALINYAMATAN ... WASIS: Jurnal Ilmiah Kependidikan. Volume 1, Nomor 2, November 2020, hlm. 60-67

observasi saat proses pembelajaran dengan didasarkan pada nilai Kriteria Ketuntasan Minimal (KKM) ranah sikap dan ranah keterampilan yaitu 65. Adapun hipotesis yang diajukan sebagai berikut

Ho: rata-rata aktivitas belajar siswa kelas IV SDN 1 Damarjati dengan pembelajaran model Group Investigation berbantuan media Watak Kalinyamatan $\geq 65$.

Ha: rata-rata aktivitas belajar siswa kelas IV SDN 1 Damarjati dengan pembelajaran model Group Investigation berbantuan media Watak Kalinyamatan $<65$.

Pengambilan keputusan dan penarikan kesimpulan menggunakan taraf kepercayaan $95 \%$ dengan kriteria, jika $P$-value $>1 / 2 \alpha$, maka $\mathrm{H}_{0}$ diterima dan jika $P$-value $\leq 1 / 2 \alpha$, maka $\mathrm{H}_{0}$ ditolak. Karena pengujian yang dilakukan adalah uji satu pihak (uji pihak kiri), maka $P$-value $=1 / 2 \times$ nilai sig. (2-tailed). Hasil uji t deskriptif aktivitas belajar siswa dapat dilihat pada Tabel 5 .

Tabel 5 Hasil Uji t Deskriptif Aktivitas Belajar Siswa

\begin{tabular}{|c|c|c|c|c|c|c|}
\hline \multicolumn{7}{|c|}{ One-Sample Test } \\
\hline & \multicolumn{6}{|c|}{ Test Value $=65$} \\
\hline & & & \multirow{2}{*}{$\begin{array}{l}\text { Sig. }(2- \\
\text { tailed })\end{array}$} & \multirow{2}{*}{$\begin{array}{c}\text { Mean } \\
\text { Difference }\end{array}$} & \multicolumn{2}{|c|}{$95 \%$ Confidence Interval of the Difference } \\
\hline & $\mathrm{t}$ & df & & & Lower & Upper \\
\hline $\begin{array}{l}\text { Nilai Aktivitas Belajar } \\
\text { Siswa Pertemuan } 1\end{array}$ & -4.579 & 44 & .000 & -3.778 & -5.44 & -2.12 \\
\hline $\begin{array}{l}\text { Nilai Aktivitas Belajar } \\
\text { Siswa Pertemuan } 2\end{array}$ & 1.257 & 44 & .215 & 1.022 & -.62 & 2.66 \\
\hline $\begin{array}{l}\text { Nilai Aktivitas Belajar } \\
\text { Siswa Pertemuan } 3\end{array}$ & 1.730 & 44 & .091 & 1.533 & -.25 & 3.32 \\
\hline $\begin{array}{l}\text { Nilai Aktivitas Belajar } \\
\text { Siswa Pertemuan } 4\end{array}$ & 1.825 & 44 & .075 & 1.689 & -.18 & 3.55 \\
\hline
\end{tabular}

Berdasarkan hasil uji t deskriptif aktivitas belajar siswa pada Tabel 5, didapatkan bahwa nilai sig. (2-tailed) pada pertemuan 1 sebesar 0,000. $P$-value $=1 / 2 \times 0,000=0$. Karena $P$-value $<$ $1 / 2 \alpha,(0<0,025)$ maka $\mathrm{H}_{0}$ ditolak dan dapat disimpulkan bahwa rata-rata aktivitas belajar siswa pada pertemuan 1 mendapatkan nilai $<65$. Artinya aktivitas belajar siswa kelas IV SDN 1 Damarjati dengan pembelajaran model Group Investigation berbantuan media Watak Kalinyamatan pada pertemuan 1 kurang dari KKM.

Uji $\mathrm{t}$ deskriptif aktivitas belajar siswa pertemuan 2 didapatkan nilai sig. (2-tailed) sebesar 0,215. P-value $=1 / 2 \times 0,215=0,1075$ Karena $P$-value $\geq 1 / 2 \alpha,(0,1075 \geq 0,025)$ maka $\mathrm{H}_{0}$ diterima dan dapat disimpulkan bahwa aktivitas belajar siswa pada pertemuan 2 mendapatkan nilai $\geq 65$. Artinya aktivitas belajar siswa pada pertemuan 2 lebih dari atau sama dengan KKM.

Pada uji t deskriptif aktivitas belajar siswa pertemuan 3 didapatkan nilai sig. (2-tailed) sebesar 0,091. P-value $=1 / 2 \times 0,091=0,045$. Karena $P$-value $\geq 1 / 2 \alpha,(0,045 \geq 0,025)$ maka $\mathrm{H}_{0}$ diterima dan dapat disimpulkan bahwa aktivitas belajar siswa pada pertemuan 3 mendapatkan nilai $\geq 65$. Artinya aktivitas belajar siswa pada pertemuan 3 lebih dari atau sama dengan KKM.

Pada uji t deskriptif aktivitas belajar siswa pertemuan 4 didapatkan nilai sig. (2-tailed) sebesar 0,075. P-value $=1 / 2 \times 0,075=0,037$. Karena $P$-value $\geq 1 / 2 \alpha,(0,037 \geq 0,025)$ maka $\mathrm{H}_{0}$ diterima dan dapat disimpulkan bahwa aktivitas belajar siswa pada pertemuan 4 mendapatkan nilai $\geq 65$. Artinya aktivitas belajar siswa pada pertemuan 4 lebih dari atau sama dengan KKM.

Penggunaan model Group Investigation berbantuan media Watak Kalinyamatan menjadikan siswa aktif dalam mengikuti pembelajaran. Siswa berlomba-lomba menyelesaikan soal-soal yang dijumpainya dalam permainan Watak Kalinyamatan. Selain itu antara kelompok satu dengan kelompok lain berlombalomba menyelesaikan permainan dan berebutan untuk mempresentasikan hasil investigasi yang telah dilakukan. Kegiatan diskusi kelompok pada model Group Investigation membantu melatih siswa untuk aktif menyampaikan pendepatnya, sehingga aktivitas siswa meningkat. Hal tersebut selaras dengan pendapat Malik (2019) bahwa pemberian kegiatan diskusi kelompok dapat mengaktifkan siswa yang diam untuk dapat mengungkapkan pendapatnya. Berdasarkan hal 
Nurlaely Dwi Astuti, Muhammad Noor Ahsin, dan Siti Masfuah

EFEKTIVITAS MODEL GROUP INVESTIGATION BERBANTUAN MEDIA WATAK KALINYAMATAN ... WASIS: Jurnal Ilmiah Kependidikan. Volume 1, Nomor 2, November 2020, hlm. 60-67

tersebut, dapat disimpulkan bahwa penerapan model Group Investigation berbantuan media Watak Kalinyamatan dapat meningkatkan aktivitas belajar siswa.

\section{SIMPULAN}

Berdasarkan hasil penelitian, dapat disimpulkan bahwa model Group Investigation berbantuan media Watak Kalinyamatan efektif dalam meningkatkan pemahaman konsep siswa kelas IV SDN 1 Damarjati. Penerapanmodel Group Investigation berbantuan media Watak Kalinyamatan juga meningkatkan aktivitas belajar siswa pada setiap pertemuan dan mencapai Nilai Ketuntasan Minimal (KKM) 65.

\section{DAFTAR PUSTAKA}

Ardianti S.D., Wanabuliandari S., \& Rahardjo S. 2019. The Implementation Of E-Jas Science Edutainment To Improve Elementary School Student'sconceptual Understanding. Unnes Science Education Journal, 8 (1), 1-6

Cahyani, Hesti dan Ririn Wahyu Setyawati. 2016. "Pentingnya Peningkatan Kemampuan Pemecahan Masalah melalui PBL untuk Mempersiapkan Generasi Unggul Menghadapi MEA"

Fujiawati, Fuja Siti. 2016. Pemahaman Konsep Kurikulum Dan Pembelajaran Dengan Peta Konsep Bagi Mahasiswa Pendidikan Seni. Jurnal Pendidikan dan Kajian Seni, 1 (1).

Juliarto, F. F., Oktavianti, I., \& Purbasari, I. (2020). Implementasi Media Utangklek Terhadap Peningkatan Hasil Belajar Siswa Sekolah Dasar. WASIS: Jurnal Ilmiah Pendidikan, 1(1), 36-43.

Khotimah, Nur. 2016. Keefektifan Model Group Investigation terhadap Hasil Belajar PKn Materi Globalisasi Siswa Kelas IV di SD Gugus Srikandi Kota Semarang:

Kristin, Firosalia. 2018. Meta Analisis Pengaruh Model Pembelajaran Role Playing Terhadap Hasil Belajar IPS. Jurnal Refleksi Edukatika, 8 (2): 2.

Lestari, Karunia Eka dan Mokhammad Ridwan Yudhanegara. 2017. Penelitian Pendidikan Matematika. Bandung: PT Refika Aditama.
Malik, Jamaludin. 2019. Penerapan Metode Diskusi Kelompok untuk Meningkatkan Hasil Belajar IPA dan Aktivitas Siswa Kelas IV SD 1 Sidorekso Pada Materi Menggolongkan Hewan Berdasarkan Jenis Makanannya. Jurnal Refleksi Edukatika, 9(2), 128-133

Mardapi, Djemari, Samsul Hadi, Heri Retnawati. 2015. Menentukan Kriteria Ketuntasan Minimal Berbasis Peserta Didik. Jurnal Penelitian dan Evaluasi Pendidikan, 19 (1).

Ningsih R, Ardianti SD, \& Purbasari I. 2020. Penerapan Model Group Investigation Berbantu Media Gambar Berseri Untuk Meningkatkan Keterampilan Menulis Siswa. Kreatif: Jurnal Kependidikan Dasar, 11(1), 17-27.

Pranata, Ella. 2016. Implementasi Model Group Investigation (GI) berbantuan Alat Peraga untuk Meningkatkan Kemampuan Pemahaman Konsep Matematika. Jurnal Pendidikan Matematika Indonesia, 1 (1).

Shoimin, Aris. 2014. 68 Model Pembelajaran Inovatif dalam Kurikulum 2013. Yogyakarta: Ar-Ruzz Media.

Sholichah, Aas Siti. 2018. Teori-Teori Pendidikan dalam Al-Qur'an. Jurnal Edukasi Islami Jurnal Pendidikan Islam, 7 (1).

Siregar, Ruslan. 2017. Penggunaan Media Gambar untuk Meningkatkan Hasil Belajar IPA Pada Siswa Sekolah Dasar. Jurnal Ilmu Pendidikan Sosial, Sains, dan Humaniora, 3 (4).

Sugiyono. 2016. Metode Penelitian Pendidikan Pendekatan Kuantitatif, Kualitatif, dan $R \& D$. Bandung: Alfabeta.

Sukiman. 2012. Pengembangan Media Pembelajaran. Yogyakarta: Pedagogia.

Zafira, H \& Artharina, F.P. 2017. Pengembangan Media Wayang Tematik Pada Tema Indahnya Negeriku Sebagai Pendukung Scientific Approach Kelas IV Sekolah Dasar. Jurnal Refleksi Edukatika, 8(1), 9-15 